\title{
СТРАТЕГІЧНІ ПРИНЦИПИ В СИСТЕМІ ОРГАНІЗАЦІї ЗДОРОВ’ЯЗБЕРІГАЮЧОЇ ОСВІТИ У ШКОЛІ ТА ВНЗ
}

\footnotetext{
У статті наводяться пріоритетні завдання педагогічних кадрів, здатних творчо й ефективно працювати в нових умовах для збереження та змічнення здоров'я підростаючого покоління.

Ключові слова: здоров 'язберігаючий компонент, валеологічний приниип освіти, формування і збереження здоров'я.

В статье приводятся приоритетные задачи педагогических кадров, способных творчески и эффективно работать в новых условиях для сохранения и укрепления здоровья подрастающего поколения.

Ключевые слова: здоровьесберегающий компонент, валеологический приниип образования, формирование и сохранение здоровья.
}

The priority task of pedagogical stall that capable of working creatively and efficiently in new conditions with the use of health preservation principles of education and upbringing of rising generation are analyzed.

Key words: health preservation component, valeologic principle of education, formation and saving of health.

Meта статmi: проаналізувати стратегічні принципи в системі організації здоров'язберігаючої освіти в середній і вищій школі.

Відповідно до Національної доктрини розвитку системи освіти в Україні в XXI ст. пріоритетними напрямками є: збереження i зміцнення здоров'я школярів і студентської молоді; формування в майбутніх учителів, школярів стійкої мотивації на здоровий спосіб життя, навичок дбайливого ставлення до свого здоров'я і здоров'я й життя інших, уміння своєчасно приймати рішення, спрямовані на профілактику шкідливих звичок, бажання створити або знайти умови для тривалої активності життя.

Нині однією $з$ причин низького рівня здоров'я молоді є відсутність ціннісних орієнтацій на здоров'я і формування навичок здорового способу життя. Це твердження багато в чому зумовлено тим, що для молоді багатьох поколінь взагалі характерне послаблення інстинкту самозбереження, а в сучасної молоді, зокрема, бажання і прагнення задоволення своїх потреб розвиваються швидше, ніж воля і сила характеру $[7 ; 9 ; 10$,$] .$

На думку ряду вчених, процес формування настанови на здоров'я і культуру здорової поведінки серед дітей та підлітків допускає наявність цілеспрямованої і керованої суспільством системи освіти і виховання, що базується на валеологічних принципах. 3 усього різноманіття можливих шляхів державної політики в забезпеченні здоров'я підростаючого покоління, основним розглядається саме педагогічний аспект: вплив педагогічними засобами на формування, збереження та зміцнення здоров'я людини $[2 ; 3 ; 6]$.

Одним з аспектів сучасної освіти є завдання виховання в дітей та підлітків потреби у здоров'ї як життєво важливої цінності, свідомого прагнення до ведення здорового способу життя, до «самотворення» i творення навколо себе здорового середовища проживання - формування валеологічної культури особистості як частини ії загальної культури.

Весь процес навчання і виховання повинен бути налаштований таким чином, щоб протягом усього життя в людини поповнювалася і відтворювалася індивідуальна і суспільна пам'ять, яка підлягає вдосконаленню на всіх етапах життєдіяльності. Саме школа, ВНЗ, суспільство, довкілля формують у свідомості людини такі якості, як: пам’ять, інтелект, мислення, увагу, виховання, які є передумовою розвитку мотивації, переконання, цілеспрямованості та формування здорового способу життя, що становить (50\%) основи здоров'я. Особистість із розвиненою свідомістю - самостійна й відповідальна, вона спроможна протистояти впливу зовнішніх негативних чинників, долати труднощі, досягати поставленої мети й залишатися здоровою, надовго зберігаючи працездатність і активне довголіття.

Система загальної та вищої освіти не може вважатися науковою та гуманістичною, оскільки цінності здоров'я суб'єктів цього процесу не знаходять належного місця в ії навчальних планах. Систему організації здоров'язберігаючої освіти ВНЗ можна розглядати як: 1) оволодіння комплексомзнань, умінь, якостей особистості; 2) і їх подальшого розвитку, які покликані забезпечити їй можливість протягом усього життя здійснювати ефективну професійну діяльність, засновану на пріоритеті здоров'я [5].

Для формування і розвитку в майбутніх педагогів «профілактичної логіки», «професійної думки», об'єктивно виникла потреба впровадження в освітній процес і освітній простір педагогічних ВНЗ елементів здоров'язбереження.

Педагог - це особлива професія, але саме педагогів готують недостатньо 3 питань збереження здоров'я учнів і створення сприятливого освітнього простору. Інноваційні процеси в освіті, варіативність змісту освіти, різноманіття існуючих технологій навчання вимагають від учителя вияву системності мислення, розвитку креативних здібностей, пошуку індивідуального стилю педагогічної 
діяльності. Крім того, збільшення компонента творчої праці, згідно $з$ дослідженнями фізіологів, гарантує соціально-біологічне збереження і розвиток здоров'я, тривалість активного життя. Під впливом об'єктивних і суб'єктивних чинників поширюються ідеї про здоров'язберігаючі програми, про свободу вибору форм, методів навчання і виховання, оцінки ефективності освітнього процесу [1; $4 ; 8]$.

Одним із найбільш пріоритетних завдань освіти на сучасному етапі є підготовка педагогічних кадрів, здатних творчо й ефективно працювати в нових динамічних умовах української педагогічної діяльності.

На думку вчених, здоров'язберігаюча освіта - це така організація процесу навчання, яка дозволяє дотримуватися безпеки для здоров'я, росту і розвитку школярів й студентів, забезпечує відповідність змісту й обсягу навчального матеріалу, методів і форм навчально-пізнавальної діяльності психофізіологічним особливостям організму. Вона зберігає розумову і фізичну працездатність студентів, формує структуру здорового способу життя, забезпечує збереження та зміцнення фізичного, психічного й духовного здоров'я [8].

На думку лікарів, психологів і педагогів сучасна система дошкільного і шкільного навчання та виховання не забезпечує надійних умов для формування та збереження здоров'я дітей та підлітків. Так, до 20\% дітей 6-7 років не готові до шкільного навчання, а в багатьох школярів процес адаптації до школи відбувається зі значними труднощами; 30-35\% дітей при вступі до школи мають різні хронічні захворювання. За роки навчання в школі в 4 рази збільшується кількість порушень психічного здоров'я, у 3 рази збільшується кількість дітей із захворюваннями органів травлення; до $70 \%$ збільшується кількість школярів із порушеннями опорно-рухового апарату; зору (50\%); серцевосудинної системи (30\%); близько 90\% дітей шкіл мають відхилення у фізичному та психічному здоров 'ї; у 80\% студентів фіксується порушення здоров'я різного ступеня тяжкості $[2 ; 5 ; 6 ; 7]$.

Нині існує об'єктивна необхідність у створенні та реалізації здоров'язберігаючих програм у педагогічному ВНЗ, наповненні їх власним, неповторним змістом для кожного навчального закладу, 3 урахуванням його цілей, завдань і потреб студентів і викладачів.

Однак, застосування здоров'язберігаючих принципів i методів забезпечення педагогічної діяльності вимагає від учителя досить глибоких і грунтовних знань, фізіологічних і психологічних закономірностей росту і розвитку дітей, чіткого уявлення про фізіолого-гігієнічні нормативи та вимоги, які висуваються до середовища навчання, уміння грамотно і сучасно використати методи діагностики та, коли необхідно, вдаватися до корекції порушень стану здоров'я учнів. Без цього важко досягти ефективності та якості засвоєння знань, не може бути й мови про індивідуалізацію та гуманізацію процесу освіти.

Педагог, володіючи сучасними науково-педагогічними знаннями, у тісній взаємодії зі школярами та їх батьками, медичними працівниками, психологами, колегами планує свою роботу з урахуванням пріоритетів збереження і зміцнення здоров’я всіх учасників педагогічного процесу.

Збереження здоров'я в школі є одним із завдань загального освітнього процесу, що розв'язується в таких напрямках: 1) медико-гігієнічні напрямки (педагог - медичний працівник - учень); 2) фізкультурно-оздоровча спрямованість (перевага надається занятям 3 фізичної культури); 3) екологічна спрямованість (створення гармонійної взаємодії з природою, використання природних чинників оздоровлення); 4) культурно-естетична спрямованість (широке використання хорового співу, хореографія, розважальні вечори); 5) комплексна здоров'язберігаюча спрямованість, коли одночасно поєднуються різного виду спрямованості.

Основний показник, за яким здоров'язберігаючі освітні технології відрізняються від класичних педагогічних технологій, виявляється у проведенні регулярної експрес-діагностики стану здоров'я школярів і студентів, у моніторингу основних параметрів розвитку організму в динаміці, що дозволяе зробити відповідні висновки про стан здоров'я школярів або студентів і своєчасно запропонувати лікувально-оздоровчі заходи.

Упровадження здоров'язберігаючого компонента в навчальний процес школи та ВНЗ передбачає розвиток морального потенціалу, який $\epsilon$ складовою частиною здоров'я людини. При цьому валеологічну освіту і виховання всього населення України слід уважати стратегічним завданням держави.

в. Системный подход в формировании здорового образа жизни субъектов образовательного процесса «школа - вуз» / Н. П. Абаскалова. - Новосибирск, 2001. - 156 с. 2. Айзман Р. И. Педагогические и медицинские проблемы / Р. И. Айзман // Материалы международной конференції.Новосибирск, 1999. - С. 18-21. 3. Апанасенко Г. Л. Медицинская валеология / Г. Л. Апанасенко, А. А. Попова. - К., 2000. - 248 с. 4. Березина М. Г. Роль психофизиологических особенностей студентов в адаптации к учебной деятельности : автореф. дис. на соискание научн. степени канд. пед. наук / М. Г. Березина. Новосибирск, 2000. 5. Зайцев Г. К. Валеология. Культура здоровья / Г. К. Зайцев, А. Г. Зайцева. - Самара, 2003. - 272 с. 6. Казин Э. М. Основы индивидуального здоровья человека / Э. М. Казин. - М., 2000. - 192 с. 7. Малашенко М. П. Педагогика здоровья в начальной школе / М. П. Малашенко. - Харьков, 2008. - 192 с. 8. Мельникова М. М. Концептуальные подходы к системе организации здоровьесберегающего образования в вузе / М. М. Мельникова // Валеология. - 2006. - №1. - С. 80-83. 9. Практикум по психологии здоровья / под 
ред. Г. С. Никифорова. - СПб., 2005. - 351 с. 10. Тимофієва М. П. Психологія здоров'я : [навч. посібн.] / М. П. Тимофієва, О. В. Двіжанова. - Чернівці, 2009.- 296 с. 